\title{
ASYNCHRONOUS COMPUTER MEDIATED COMMUNICATION: AN EXPLORATORY STUDY ON STUDENTS' E-LEARNING EXPERIENCE AND THEIR INTERACTION
}

\author{
Dian Resty Pratiwi Ahmad \\ Faculty of English Education, Lakidende University \\ Sultan Hasanuddin Street No. 234 Konawe, Southeast Sulawesi, Indonesia. 93411 \\ Email: dianpratiwi.edu31@gmail.com
}

\begin{abstract}
Asynchronous CMC is an online learning that has time difference between the period of teaching using online apps and the messages. This study aimed to find out students' interaction and activities on the asynchronous CMC through Google Classroom and Whatsapp Group. This study employed mixed method namely exploratory research design. There were 20 participants involved as the sample of this study. The qualitative data were collected and analysed in order to develop the quantitative instrument. Thus, this research used observation recordings and questionnaire which consisted of 12 main questions. This study found that at least there are four main activities on asynchronous learning namely communication, learning process, material and evaluation. The participants showed different responses in two activities namely communication and learning process in both applications namely Whatsapp and Google Classroom. Meanwhile, in material and evaluation the participants showed relatively similar percentage. Besides, this study found that traditional faceto-face learning is easier than online learning in terms of communication and learning materials. This study suggests that the details of this finding need to be investigated further.
\end{abstract}

Keywords: asynchronous learning, observation, online, exploratory research design

\begin{abstract}
Abstrak: Asynchronous CMC adalah pembelajaran online yang memiliki perbedaan waktu antara periode pengajaran menggunakan aplikasi online dan pesan. Penelitian ini bertujuan untuk mengetahui interaksi dan aktivitas siswa pada CMC asynchronous melalui Google Classroom dan Whatsapp Group. Penelitian ini menggunakan metode campuran yaitu desain penelitian eksploratif. Sampel penelitian ini berjumlah 20 orang. Data kualitatif dikumpulkan dan dianalisis untuk mengembangkan instrumen kuantitatif. Oleh karena itu, penelitian ini menggunakan rekaman observasi dan kuesioner yang terdiri dari 12 pertanyaan utama. Penelitian ini menemukan bahwa setidaknya ada empat kegiatan utama pada pembelajaran asinkron yaitu komunikasi, proses pembelajaran, materi dan evaluasi. Respon peserta menunjukkan perbedaan dalam dua kegiatan yaitu komunikasi dan proses pembelajaran di kedua aplikasi yaitu Whatsapp dan Google Classroom. Sedangkan pada materi dan evaluasi peserta menunjukkan persentase yang relatif sama. Selain itu, penelitian ini menemukan bahwa pembelajaran tatap muka tradisional lebih mudah daripada pembelajaran online dalam hal komunikasi dan materi pembelajaran. Studi ini menunjukkan bahwa rincian temuan ini perlu diselidiki lebih lanjut.
\end{abstract}

Kata Kunci: daring, desain penelitian eksplorasi, observasi, pembelajaran asinkron

\section{Introduction}

As the online learning increases to gain popularity, lecturers are increasingly employing more effective online learning applications to accommodate the students' learning. The growing implementation of synchronous, asynchronous and hybrid learning are as the result of high demand on online education as stipulated on ministry of education and culture regulation number No. 4 year 2020 which states that online learning should be implemented due to the pandemic. Besides, online learning and hybrid learning have been implemented to complement the classroom-based classes (Kusumo et al., 2012).

Despite the growing interest of online based learning, the lecturers and students deal with some issues. The fact shows that many students live in the rural area with low internet connection thus they complain the online studying. Rahayu (2020) explained that after more than a decade of the growing implementation of e-learning in Indonesia many successes have been found. Yet, research that has been conducted has found that the users of technology in education in Indonesia still find some obstacles. Some main problems faced by students in general are about their independency, connection problem, and lack of familiarity with the online materials (Kusumo et al., 2012). On the other hand, Okmawati 
(2020) revealed that using Google Classroom was effective in improving the students' skills. Besides, asynchronous system improves the assessment of students' learning process in which this platform can keep the records of students' activities on online classroom including discussion threads, interaction with their peers and teachers becoming data source of learning assessment (Shi et al., 2006; Hew et al., 2010; Tanimoto et al., 2002).

Synchronous learning environments provide real time interaction, which can be collaborative in nature incorporating e-tivities such as an instructor's lecture with a facility of questions-answer session. It requires simultaneous student-teacher presence. On the other hand, asynchronous environments are not time bound and students can work on e-tivities on their own pace (Salmon, 2013). Aside from the advantage of online learning, some opinions showed a great concern on the online learning outcomes. DiPiro (2003) stated that scholars believe the instruction quality and students' ability should be observed and assessed as new technologies are involved. Without interaction, students' learning can hardly result satisfactory outcomes and students may experience isolation (Haythornthwaite \& Kazmer, 2002). Hence, it is important to investigate the use of online apps especially asynchronous to see how it works on students' learning process.

In Islam, the importance of using appropriate media in communication, including teaching, has started when Prophet Sulaiman used the Hud-hud birds as the advance communication technology to deliver messages to Queen Bilqees so that the essence of the information could be accepted as intended. This story is mentioned in QS An-Naml (27) 29-30 as follows:

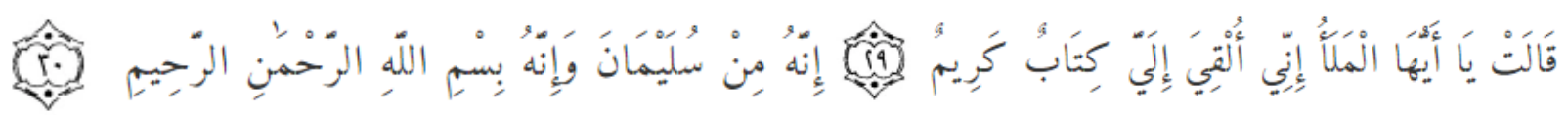

Meaning:

"She said, "O eminent ones, indeed, to me has been delivered a noble letter. (29) Indeed, it is from Solomon, and indeed, it is [i.e., reads]: 'In the name of Allah, the Entirely Merciful, the Especially Merciful, (30)"

Many studies have been conducted on online apps, yet there are still few studies focused on exploring students' interaction and activities on synchronous E-learning. Understanding their learning experience and activities will result more innovation and improvement on online learning. Therefore, the objectives of this research are to find out students' interaction on the asynchronous learning through Google Classroom and to investigate their activities on asynchronous learning.

\section{Materials and Methods}

\section{A. Research Design}

This research used the combination of qualitative and quantitative research (mixed method research design). Mixed method is a research design with philosophical assumptions that guide the direction as well as methods of inquiry (Creswell \& Clark, 2010). Exploratory sequential design is one of Creswell's (2014) mixed research designs started with qualitative exploratory data. Then, the qualitative phase is used to develop quantitative instruments and distributed to the participants (Creswell, 2014); Creswell \& Clark, 2010). The quantitative phase then was used to interpret the final data analysis of this study.

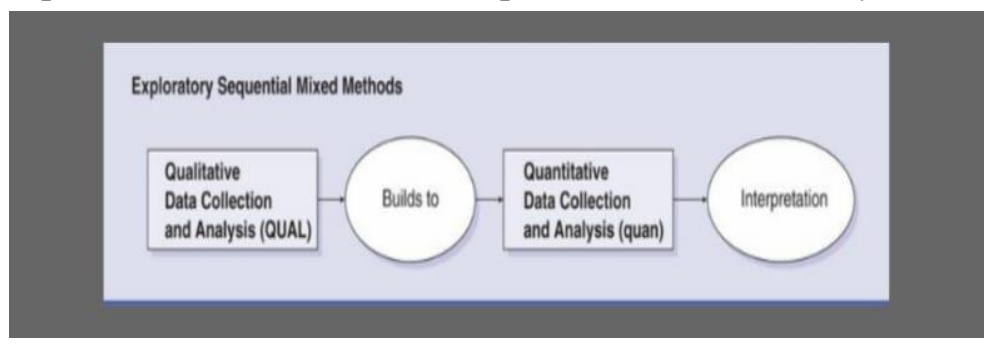

Figure 1. Exploratory Sequential Design Mixed Method

The qualitative data were collected first through some steps: (1) coding all the collected data in this case the observation result, (2) reading through all the data, (3) organizing and preparing all the qualitative 
data for analysis and interpreting the data. Then, the result of qualitative analysis was used to develop the questionnaire and it was analysed quantitatively.

The aim of exploratory sequential research design in this study was to find out students' interaction and what the students perceived from the implementation of asynchronous learning through Whatsapp and Google Classroom. In the first qualitative phase, the research question was focused on observing the e-learning process through different online applications; Whatsapp and Google Classroom to investigate the activities. In the second quantitative phase, a questionnaire consisted of 12 questions asking about what students perceived from the activities in e-learning through Whatsapp compared to Google Classroom and also what they perceived from e-learning in comparison to traditional face-to-face learning.

B. Time and Allocation

This research was conducted in a year and it was conducted in one of private universities in Southeast Sulawesi namely Lakidende Unaaha University in order to get the data in accordance with the problem statements and the objectives of this research.

C. Population and Sample

The population of this study was the students of Economics and Business Faculty of Universitas Lakidende Unaaha in academic year 2021/2022. The selected sample was based on purposive sampling technique). This purposive sampling is one of the sampling techniques mostly used in qualitative study (Sugiyono, 2014). The participants were the students of Economics and Business Faculty who were taught TOEFL basic course through Google Classroom and Whatsapp Group. There were 20 students involved as the sample of this study.

D. Instrument of Data Collection

There were two different instruments used to gather the data they were observation recordings and questionnaire. The initial data collection process was observation. It was carried out both in Whatsapp group and classroom hence the chat rooms were recorded and captured. After the observation was done, the questionnaire was organized and distributed to the participants. Dornyei (2003) explains that questionnaire is a survey instruments for the purpose of investigating the data on attitudes opinions, beliefs and motivations in learning language. In this study, the result of observation was used to develop the question in the questionnaire which was then presented in the form of percentage.

E. Procedure of Data Collection

Firstly, the researcher observed the E-learning to investigate their interaction in order to classify the kinds of activities of the students that occurred during online learning through Whatsapp and Google Classroom. The observation checklist was used and it was focused on teacher and students' learning activities on both online applications; Whatsapp and Google Classroom and it was adapted from (Brown, 2007). Secondly, the questionnaire which consists of 12 questions were utilized to get more in depth data about students' perception on the implementation of online learning using Whatsapp group and Google Classroom. A set of closed-item questionnaire using five options Likert Scale answers was used to gather the data.

F. Techniques of Analysing the Data

Firstly, the qualitative data was analysed through some steps: (1) Reading, in which the researcher read and wrote the memos about all field notes to get an initial data. (2) Describing, it involved developing comprehensive descriptions of the participants and the phenomenon. The description was based on observation results. The purpose of this phase was to provide a narrative picture of the setting of an event. (3) Classifying was aimed to categorize the data, to organize and to group them into the themes (Gay \& Airasian, 2006). The result of questionnaire was analysed quantitatively for the frequency to find the answers of the second research question and objective of the study.

\section{Results and Discussion}

Based on the collected data, there were some interesting findings which are presented and discussed below: 


\section{A. The students' interaction on synchronous learning through Google Classroom and Whatsapp group}

The observations showed different results in terms of students' interaction during the lessons and they are showed on the following chat rooms and history.

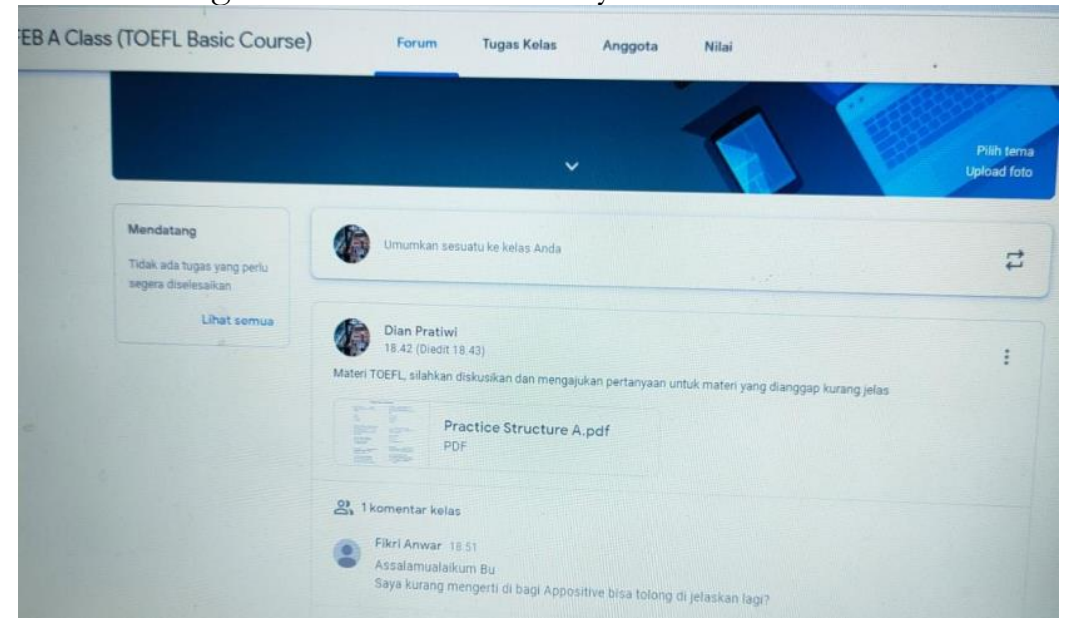

Figure 2. Students' participation on Google Classroom

The Figure 2 is a capture of students' participation and activities. The researchers uploaded the TOEFL material and allow the participants to ask questions and give comments. The questions and also comments were considered and classified as students' active participation on the class. Then, the students give the written questions and comments in the chatrooms since in Google Classroom the students preferred giving written comments than using audio and video recording features.

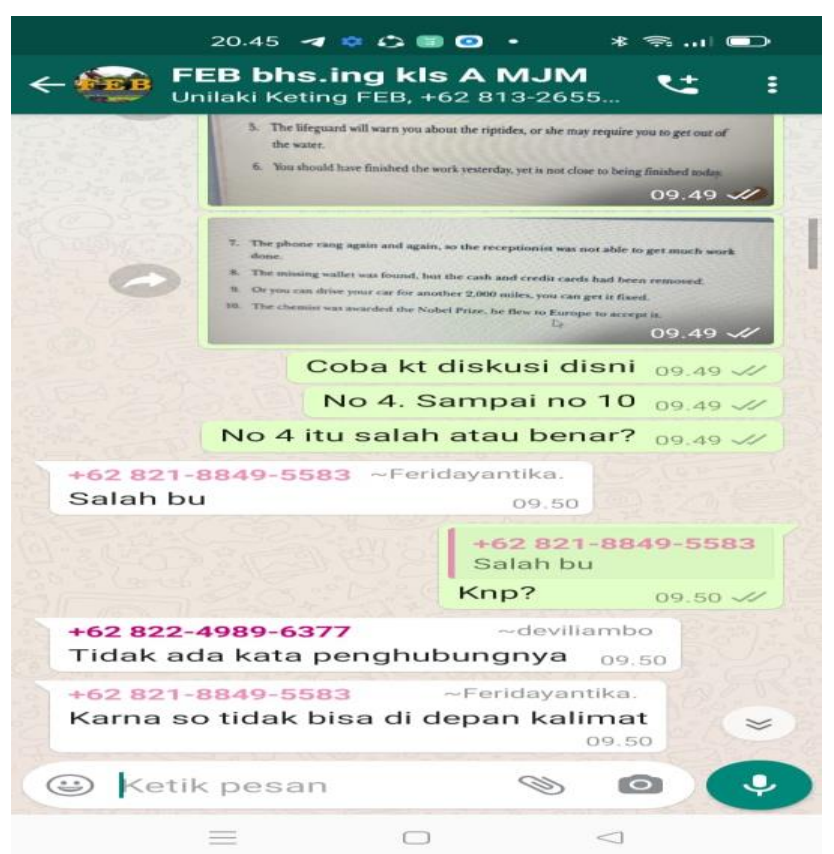

Figure 3. Students' Participation on Whatsapp Group

The Figure 3 is a capture the students' written communication on Whatsapp group. The teacher posted the material and explained it. The chat history shows that the students tend to give written than spoken comments despite the video and audio recording features on Whatsapp group this is similar to Google Classroom (see Figure 1). Besides, the teachers could also give direct response and feedback on students' questions and answers. 
Then, based on the above Figure 1 and 2 the researchers draw the categorization of students' activities. There are 4 main categories which consist of some activities in each category as presented in Table 1:

Table 1. Activities during e-learning

\begin{tabular}{lc}
\hline Activities & Category \\
Quessroom lecture to all students & \\
Group discussion & Communication \\
Quiz & \\
Teachers' feedback & Material \\
Shared materials & \\
Download the materials and exercises & \\
Upload the answers of exercises & Learning Process \\
Written explanation from the teachers & \\
Response and Comments on the materials & \\
Questions and answers about the lesson & \\
Classroom practice through shared materials & \\
Individual work & Evaluation \\
Students' Participation & \\
Exercise result & \\
Quiz &
\end{tabular}

It can be clearly seen from the table 1 that the activities are categorized into four main themes namely communication, material, learning process and evaluation. This is similar to a study conducted by Rahayu (2020). In her study, she found that at least there are three aspects of students' activities in synchronous learning namely communication, materials and study process. In communication, it consists of some sub components and it is carried out mainly through written manner. The sub components (see table 1) include the classroom lecture, question and answer session, group discussion, quiz and teachers' feedback. The second category of activities is material to which the teachers share the lesson matters then the students can directly download and upload the answers also comments related to the subjects (see table 1). In the learning process, the teachers explain the lesson and the students were given chance to ask questions related to the material. The classroom practice was aimed to enable students to practice the lesson. From the observation, the data reveals that the students were more active to give comments and questions on Whatsapp group than on Google Classroom. This is indicated by the amount number of comments on Whatsapp group in comparison to only small number on Google Classroom (see Figure 2 and 3).

\section{B. Students' perception about implementation of asynchronous through Google Classroom and Whatsapp group}

There are 12 number of items in the questionnaire asking about the opinion of students regarding asynchronous learning through Google Classroom and Whatsapp group. The questionnaire was built based on the result of observation and it is presented in the form of percentage in Table 2.

As seen in the Table 2 that the result of questionnaire relating to students' perception on the implementation of asynchronous learning through two different applications namely Whatsapp group and Google Classroom. The questionnaire was assessed using a likert scale and the result of each statement on the questionnaire relating to 4 main categories of students' activities are presented in detail as follows:

1. Communication

In communication activity, (questions number 1 and 2 on the questionnaire), the participants were more satisfied with Whatsapp than Google Classroom. More than $47 \%$ participants agreed that they can communicate at ease with their lecturer in Whatsapp compared to only $27.5 \%$ in Google Classroom. Communication in Whatsapp and Google Classroom can be in spoken and written form. Mostly, the students communicate in written form which was showed by their chats. The spoken communication 
between lecturers and the students is accommodated through the chat room (see Figure 1 and Figure 2). Different with Google Classroom, most of the students are already familiar with Whatsapp in which they use it for their daily communication purpose. Therefore, they are more active in having discussion with the lecturers and their friends in this case the others students in chit-chat room compared to Google Classroom. They can ask the questions to the lecturers and get the explanation. Alderman (2017) explains that using Whatsapp group create easy communication to discuss the materials. The students have been familiar with sharing information using Whatsapp through messages, videos, audios, photos, or screenshots. Likewise, Barus \& Simanjuntak (2020) on their study they found that the students' were comfort in communicating through Whatsapp group and Google Classroom during their e-learning.

Table 2. Measures of frequency from the questionnaire (percentage)

\begin{tabular}{|c|c|c|c|c|c|}
\hline Statements & $\begin{array}{l}\text { Strongly } \\
\text { Disagree }\end{array}$ & Disagree & Neutral & Agree & $\begin{array}{l}\text { Strongly } \\
\text { Agree }\end{array}$ \\
\hline $\begin{array}{l}\text { 1.I can communicate easily with my lecturer in Google } \\
\text { Classroom }\end{array}$ & $1.1 \%$ & $3.2 \%$ & $30.2 \%$ & $38 \%$ & $27.5 \%$ \\
\hline $\begin{array}{l}\text { 2.I can communicate easily in written with my lecturer in } \\
\text { Whatsapp group }\end{array}$ & $1 \%$ & $1.1 \%$ & $20 \%$ & $30.9 \%$ & $47 \%$ \\
\hline $\begin{array}{l}\text { 3. I can download and get the material from Google } \\
\text { Classroom easily }\end{array}$ & $2 \%$ & $2.7 \%$ & $23.3 \%$ & $30 \%$ & $42 \%$ \\
\hline $\begin{array}{l}\text { 4.I can download and get the material from Whatsapp } \\
\text { group easily }\end{array}$ & $0,7 \%$ & $1 \%$ & $15.5 \%$ & $29.8 \%$ & $53 \%$ \\
\hline 5.I get the feedback from my lecturer in Google Classroom & $2 \%$ & $3 \%$ & $20 \%$ & $30 \%$ & $45 \%$ \\
\hline $\begin{array}{l}\text { 6.I get the feedback from my lecturerin Whatsapp } \\
\text { classroom }\end{array}$ & $1 \%$ & $1 \%$ & $14 \%$ & $32 \%$ & $52 \%$ \\
\hline $\begin{array}{l}\text { 7.I can share my ideas and answer easily on Google } \\
\text { Classroom }\end{array}$ & $20 \%$ & $15 \%$ & $20 \%$ & $18 \%$ & $27 \%$ \\
\hline 8.I can share my ideas and answer easily Whatsapp group & $0.7 \%$ & $1.3 \%$ & $18 \%$ & $20 \%$ & $60 \%$ \\
\hline 9.I always open my Google Classroom to check my class & $35 \%$ & $30 \%$ & $10 \%$ & $15 \%$ & $10 \%$ \\
\hline 10.I always open my Whatsapp group to check my class & $1 \%$ & $1 \%$ & $3 \%$ & $30 \%$ & $65 \%$ \\
\hline $\begin{array}{l}\text { 11.I can discuss with my lecturer in face to face easier than } \\
\text { in online meeting }\end{array}$ & $2 \%$ & $2 \%$ & $8 \%$ & $30 \%$ & $58 \%$ \\
\hline $\begin{array}{l}\text { 12.Communication with my lecturer in online meeting is } \\
\text { the same as in }\end{array}$ & $40 \%$ & $25 \%$ & $10 \%$ & $10 \%$ & $15 \%$ \\
\hline
\end{tabular}

\section{Material}

The second activity is that learning materials (questions number 3 and 4 on the questionnaire) they got from both Google Classroom and whtasapp group. The questions were about the access to the learning materials from the lecturers. The data showed that $53 \%$ of participants responded very positive with the easy access to get the materials in Whatsapp similar with Google Classroom (42\% strongly agreed). The features on both online learning applications (Whatsapp and Google Classroom) enable the lecturers to share the materials easily. The lecturers distributed the documents format and shared additional materials like video and audio depending on the subject matters and students' needs. The students then can receive the notification of shared materials on both online/offline learning applications on their phone thus they can download the materials directly. This finding is similar to the result of a study conducted by (Barus \& Simanjuntak, 2020). In their study, they found the appropriateness of the learning contents which can be easily understood or comprehended by students/participants on online learning through Whatsapp and Google Classroom. The appropriateness contents were in terms of the addition of insight knowledge, students' daily lives, the accuracy of material and substance, and suitability between Whatsapp Group and Google Classroom and school's textbook/material as well.

\section{Learning Process}

The third important activity is that learning process through Google Classroom and Whatsapp group (questions number 9 and 10). From the observation in this case the chat room histories, the students on Whatsapp group tended to be more active in comparison with Google Classroom. This fact was supported by the students' response on questionnaire where $65 \%$ students agreed that they always open their Whatsapp group compared to only $10 \%$ on Google Classroom although the individual and group 
practices are shared in the same way on both applications. In comparison to a study conducted by Barus \& Simanjuntak (2020), they found that students' have positive attitudes toward the use of Whatsapp and Google Classroom especially on collaboration among students during the learning process. Thus, in order to get more comprehensive results, this question should be explored more through interview thoroughly and other instruments that can accommodate further researchers in the same field of study. Chow \& Shi (2014) stated that the learning process give the most significant impact to the satisfaction and continuity of e-learning. Another important result (based on questions number 11 and 12) found in this study was that the participants considered face-to face discussion is much easier than online learning especially in learning TOEFL.

4. Evaluation

The last question was about evaluation process (questions number 5 and 6 on the questionnaire) they have experienced through Google Classroom and Whatsapp group. The evaluation on both groups comprises three aspects; students' participation, quiz and exercise result (see Table 1). The participants on both groups gave positive answer on the evaluation process ( $45 \%$ for Google Classroom and 52\% for Whatsapp group). The features on both online learning applications are found to be effective in accommodating the evaluation process and the feedback from the lecturers. Besides, the students can access easily the task or test from the teachers and get the result and feedback from the lecturers easily. Santrossa \& Castillo (2017) mentioned that Whatsapp group could help teachers to manage large classes especially in giving feedback.

\section{Conclusion}

The finding of this study indicated there are four aspects of activities found on asynchronous learning (computer mediated communication): communication, material, learning process and evaluation. Moreover, the participants showed different responses in two activities namely communication and learning process in which the percentage in Whatsapp group in both activities was higher than in Google Classroom. Meanwhile, in material and evaluation the participants showed relatively similar percentage. Besides, this study showed that the participants always check their Whatsapp than their Google Classroom. It might be because they also use Whatsapp for other communication purposes. However, the details of this finding need to be investigated further through other data collection technique, instruments, and method. The last important point is that the participants considered that face-to-face communication is easier than online (asynchronous) learning. It can be assumed that students found it more easier to read from hardcopy books on traditional face-to-face learning than to download and upload learning materials on online platforms. The findings of this study could be used by the teachers in asynchronous learning to consider the kinds of activities that can best fit to students' needs in their online learning. Besides, the result of this study can be a reference for the lecturers in choosing the best methods and techniques in implementing asynchronous learning to the students.

\section{Acknowledgement}

The researcher would like to express her gratitude to the almighty Allah SWT for his blessings so that the researcher can finish her article. Besides, the researcher would also say thanks to all her relatives because of their supports the researcher could conduct her research.

\section{References}

Alderman, S. 2017. In 5 Ways to Use Whatsapp in the ELT Classroom. Pearson English. https://www.english.com/blog/5-waysuseWhatsapp-elt-classroom/.

Barus, I. R. G., \& Simanjuntak, M. B. 2020. whatsapp group and google classroom-based learning materials in english classes: students' perceptions. Seltics 3(1): 47-54. https://doi.org/10.46918/seltics.v3i1.552. $\backslash$

Brown, H. D. 2007. Teaching by principles: An interactive approach to language pedagogy (2nd ed.). White Plains NY: Pearson Education.

Chow, W. S., \& Shi, S. 2014. Investigating students' satisfaction and continuance intention toward e-learning: An extension of the expectation-confirmation model. Procedia-Social and Behavioral Sciences 141: 1145-1149. https://doi.org/10.1016/j.sbspro.2014.05.193. 
Creswell, John. W. 2014. Research Design: Qualitative, Quantitative, and Mixed Method Approaches (4th ed.). Thousand Oaks, CA: SAGE.

Creswell, John. W., \& Clark, V. L. P. 2010. Designing and Conducting Mixed Method Research (3rd ed.). CA: SAGE.

DiPiro, J., T. 2003. Is the quality of pharmacy education keeping up with pharmacy school expansion? American Journal of Pharmacentical Education 67(2): 207-208.

Dornyei. 2003. Questionnaires in second language research: Construction, administration, and processing. New Jersey: Lawrence Erlbaum Associates.

Gay, L. R., Mills, G. E., \& Airasian, P. 2006. Educational Research; Competencies for Analysis and Application (8th ed.). Colombus Ohio: Pearson Education.

Haythornthwaite, C., \& Kazmer, M. M. 2002. Bringing the Internet Home: Adult distance learners and their internet, home and work worlds. https://books-library.net/files/books-library.online-08131802Fl0A8.pdf

Hew, K. F., Cheung, W. S., \& Ng, C. S. L. 2010. Student contribution in asynchronous online discussion: A review of the research and empirical exploration. Instructional Science 38(6): 571-606.

Kusumo, N. S. A. M., Kurniawan, F. B., \& Putri, N. I. 2012. E-learning Obstacle Faced by Indonesian Students. The Eighth International Conference on E-Learning for Knowledge-Based Society.

Okmawati, M. 2020. The Use of Google Classroom during Pandemic. Journal of English Language Teaching 9(2): 438-443. https://doi.org/10.24036/jelt.v9i2.109293.

Rahayu, D. 2020. Synchronous zoom web conference system: An Exploratory study on students' e-learning experience. Journal of ELT Research 5(1): 68-79.

Salmon. 2013. E-tivities: The key to active online learning. London: Routledge.

Santrossa, C., \& Castillo, J. 2017. No Title. Learning Technologies Special Interest Group. https://ltsig.iatefl.org/whats-up-intheclassroom-Whatsapp.

Shi, S., Mishra, P., Bonk, Curtis. J., Tan, S., \& Zhao, Y. 2006. Thread theory: A Framework applied to content analysis of synchronous computer mediated communication data. International Journal of Instructional Technology and Distance Learning $3(3)$.

Sugiyono. (2014). Metode Penelitian Pendidikan Pendekatan Kuantitatif dan Kualitatif dan R $\odot D$. Bandung: Alfabeta.

Tanimoto, S., Carlson, A., Husted, J., Hunt, E., Larsson, J., Madigan, D., \& Minstrell, J. 2002. Text forum features for small group discussions with facet-based pedagogy. Proceedings of the Conference on Computer Support for Collaborative Learning Foundations for a CSCL Community - CSCL '02, 554. https://doi.org/10.3115/1658616.1658718 